\title{
Incidental detection of a FDG avid skin lesion: Pilar tumor in an oncologic PET/CT study
}

Zehra Pınar Koç ${ }^{1 *}$, Pelin Özcan Kara ${ }^{1}$, Bahar Ulubaş ${ }^{2}$ and Yasemin Yuyucu Karabulut ${ }^{3}$

${ }^{1}$ Medical Faculty, Department of Nuclear Medicine, Mersin University, Mersin/Turkey

${ }^{2}$ Medical Faculty, Department of Respiratory Medicine, Mersin University, Mersin/Turkey

${ }^{3}$ Medical Faculty, Department of Pathology, Mersin University, Mersin/Turkey

\begin{abstract}
Fourty nine years old female patient with history of lung operation due to lung cancer attended our department for oncologic FDG PET/CT imaging. FDG PET/ $\mathrm{CT}$ images revealed incidental detection of a scalp skin lesion with significantly increased FDG uptake. We wanted to present the PET/CT images of this rare tumor especially for this age.
\end{abstract}

\section{Case}

49 years old female patient who underwent FDG PET/CT imaging for restaging for preexisting operated lung cancer and new pleural suspicious plaques in contrast enhanced CT imaging. Significant FDG accumulation was not noticed in the pleural plaques of the patient however in the left frontoparietal region there was a hypermetabolic nodule $(14 \times 18 \mathrm{~mm}$ in dimension, SUVmax $=19.33)$ in the scalp (Figures 1 and 2). Histopathological results revealed trichilemmal cyst (pilar tumor). Pilar tumor is a malign epithelial tumor originating from the hair follicle [1]. This tumor is usually located in the scalp of advanced aged female patients and may present with additional ulceration, infection and sometimes lymph node metastasis [2]. In a previous case report metastases to the lung and intracranial involvement has been reported [3]. There is limited number of case reports with PET/CT findings in the literature [4,5]. This is the case report of a middle aged female patient with incidental detection of pilar tumor in the scalp. This tumor has high FDG affinity with high SUV levels. Additionally,

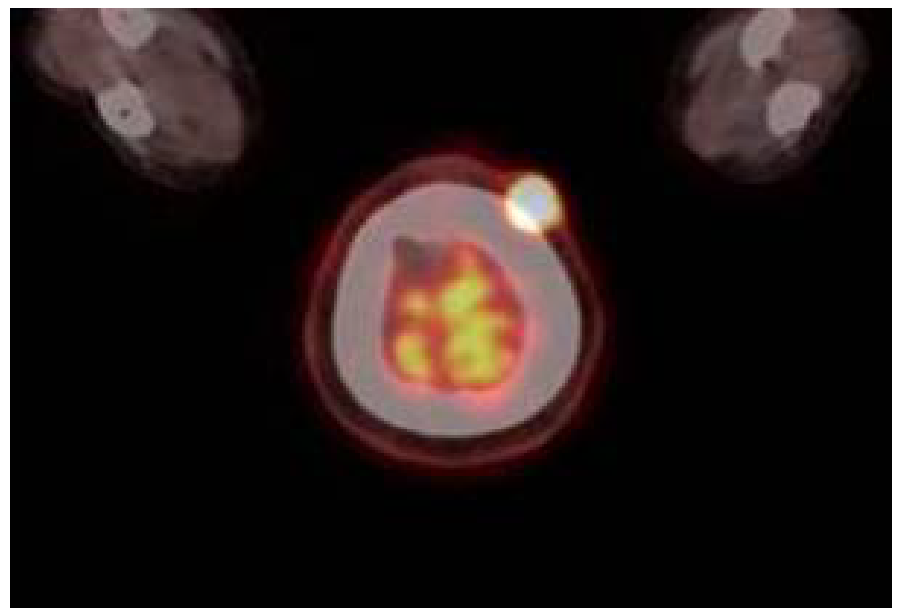

Figure 1. Transaxial fused PET/CT image of the patient including hypermetabolic skin lesion.

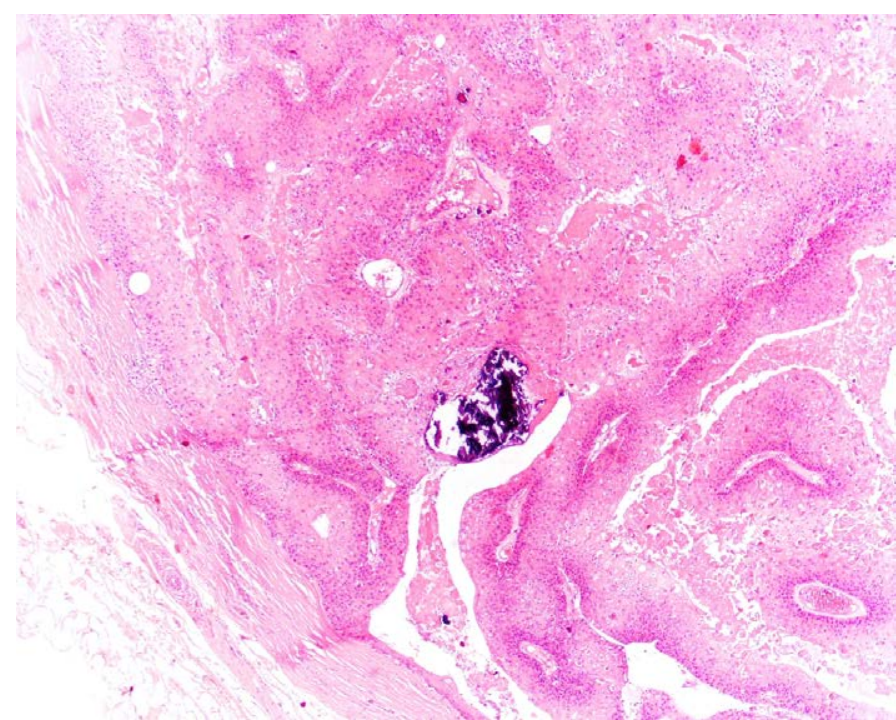

Figure 2. Hemotoksilen \& Eosin patology image: Proliferating trichilemmal cyst (tumor), well demarcated from the surrounding tissue with variably sized lobules of squamous epithelium that is thicker than seen in the pilar cyst. Characteristically, there is eosinophilic amorphous keratin in the centre of the lobules.

PET/CT may be performed to these patients in order to evaluate the lesion or staging.

\section{References}

1. Öztek İ, Baş L, Uçmaklı E, Baloğlu H (1989) İnvaziv Pilar Tümör: bir olgu bildirisi ve literatürün gözden geçirilmesi. Türk Patoloji Dergisi 74-79.

Correspondence to: Zehra Pınar Koç; Associate Professor, Medical Faculty, Department of Nuclear Medicine, Mersin University, Mersin/Turkey, Tel: +903242410000/2524, Fax:+903242410098, E-mail: zehrapinarkoc@gmail.com

Key words: pilar tumor, fluorodeoxyglucose, positron emission tomography Received: May 22, 2017; Accepted: June 05, 2017; Published: June 08, 2017 
2. Lever WF, Lever GF (1976) Histopathology of the skin, Philedelphia, Toronto, J.B. Lippincott Comp p: 379-390.

3. Lobo L, Amonkar AD, Dontamsetty VV (2016) Malignant proliferating trichilemmal tumour of the scalp with intra-cranial extension and lung metastasis-A case report. Indian J Surg 78: 493-495. [crossref]
4. Leyendecker P, de Cambourg G, Mahé A, Imperiale A, Blondet C (2015) 18F-FDG PET/ CT Findings in a patient with a proliferating trichilemmal cyst. Clin Nucl Med 40: 598599. [crossref]

5. Jung J, Cho SB, Yun M, Lee KH, Chung KY (2003) Metastatic malignan proliferating trichilemmal tumor detected by positron emission tomography. Dermatol Surg 29: 872-874. [crossref]

Copyright: $\odot 2017$ Koç ZP. This is an open-access article distributed under the terms of the Creative Commons Attribution License, which permits unrestricted use, distribution, and reproduction in any medium, provided the original author and source are credited. 